\title{
Farmers' knowledge, attitudes and practices towards rodent pests and their management in rural Pothwar, Pakistan
}

Surrya Khanam ${ }^{1,2^{*}}$ and Muhammad Mushtaq ${ }^{2}$

1. Department of Zoology, Women University Swabi-Pakistan

2. Department of Zoology, PMAS Arid Agriculture University Rawalpindi -46300-Pakistan

*Corresponding author's email: surryiamalik@gmail.com

Citation

Surrya Khanam and Muhammad Mushtaq. Farmers' knowledge, attitudes and practices towards rodent pests and their management in rural Pothwar, Pakistan. Pure and Applied Biology. Vol. 10, Issue 4, pp1181-1193.

http://dx.doi.org/10.19045/bspab.2021.100125

\begin{tabular}{llll}
\hline \hline Received: 01/09/2020 & Revised: 20/01/2021 & Accepted: 30/01/2021 & Online First: 04/02/2021 \\
\hline
\end{tabular}

\section{Abstract}

Rodents are important constraint in the agricultural systems of Pakistan. Farmers' knowledge, attitudes and practices (KAP) towards rodent pests and their management was assessed through a survey. A structured questionnaire was administrated to farmers $(n=114)$ in four villages of Pothwar, Pakistan. Farmers considered high prices of fertilizers as the major constraint in crop production. This study revealed that rodents were perceived as the major pests in both crop fields $(62 \%)$ and storage $(61 \%)$. Farmers identified wheat crop as the most susceptible to rodent attack. The harvesting stage was considered the most critical stage to rodent damage, due to high rodent population. Farmers practiced rodent management individually and considered rodenticides as the most effective way to control rodents $(88 \%)$. The majority of farmers belief that the crop production is affected due to rodent pests and in order to decrease rodent losses farmers should work together. A large portion of respondents $(77 \%)$ indicated that they lacked assistance in managing rodents. Overall, the results indicated that farmers were aware of rodent damage to crops, but lacked training on control strategies. For successful rodent pest management in Pothwar, farmers' education and training focusing on community based rodent management practices are required. In order to reduce the use of rodenticides and minimize pre- and post- harvest losses due to rodents, ecologically based management practices are highly recommended.

Keywords: Crop damages; Farmers' beliefs; Pothwar; Rodent management; Rodent pests

Introduction

Agriculture is the major component of Pakistan economy, contributing $18.9 \%$ to its Gross domestic product (GDP) and $43.2 \%$ of the labor force is associated with this sector [1]. An important problem in agriculture is the decrease in the crop yield due to rodent damages [2]. There are reports of losses of $15 \%$ and $7 \%$ in coconut and sugar cane crops, respectively from Sindh, Pakistan [3]. Also, in the grain markets of Pakistan, an estimated average population of 40 rats/grain shop and an annual grain loss of $740 \mathrm{~kg} / \mathrm{shop}$ have been reported due to various rodent activities [4]. In other developing countries of the world, rodents are considered as an important constraint in boosting agriculture [5], causing both pre- and post- harvest losses $[6,7]$. In several studies, rodents were ranked either as the most important [8-11] or as the second 
most important pest in the crop fields [12]. There are reports of rodents causing 10-15\% of loss of rice crops in Indonesia [13], and $26.4 \%$ loss of maize crop at the harvesting stage in central Ethiopia [14]. Rodents can also cause severe post-harvest losses which can result in a financial crisis for poor rural communities. In Tanzania, post-harvest losses due to rodents were reported to reach $40.4 \%$ in open cribs [15]. Similarly, in Laos, estimated grain losses of up to $10.3 \%$ during the dry season and $7.4 \%$ during the wet season have been reported [16]. In recently years, in the rural communities in Bangladesh and Myanmar loses of more than $70 \mathrm{~kg}$ and $130 \mathrm{~kg}$ of rice per year, respectively, due to the rodent pests [17]. Rodents also cause damage to buildings and households; are a nuisance for the people [18]. Rodents have also been recognized as vector and reservoirs of various zoonotic pathogens [19].

In developing countries, rodent management has always remained a major challenge for poor farmers due to their lack of knowledge about the proper control methods. Farmers consider rodents as an uncontrollable pest, and are reluctant to apply new rodent management practices [20]. In different African and Asian countries, the common control methods used by the farmers are rodent trapping, rodenticides and flooding or digging rodent burrows $[9,10,21]$. During the past decade, ecologically-based rodent management (EBRM) has been successfully conducted in many Asian countries [13, 22]. EBRM practices are recommended in Pakistan to minimize agricultural losses due to rodents. EBRM depends on a strong understanding of the ecology of the major pest species present in the area. EBRM needs to be coupled with the farmer's indigenous knowledge and practices towards rodent management. Understanting farmers' perceptions and beliefs towards rodent management can assist scientists and extension experts to plan future management strategies within the context of existing practices of farmers [23]. In Pothwar, Pakistan, little is known about the rodent pest species, their biology and distribution. Five rodents species have been reported in the cropping system of Pothwar: Golunda ellioti, Nesokia indica, Tatera indica, Bandicota bengalensis, and Mus spp. [24]. Comprehensive studies on the biology of rodent pests in both crop fields and rural commensal habitats are lacking. Also, the impact of rodent pests on the farmer communities, and perceptions of the farmers towards rodent pests and their management are not known. Hence, the aim of our study was to assess farmers' knowledge, beliefs and practices towards rodent pest management. The findings of this study along with the ecological studies on the pest species would be helpful to plan future rodent management strategies for the Pothwar region.

\section{Materials and Methods Study area}

The present survey was conducted in Pothwar $\left(32.5^{\circ} \mathrm{N}-34.0^{\circ} \mathrm{N}\right.$ and $\left.72^{\circ} \mathrm{E}-74^{\circ} \mathrm{E}\right)$ northern Punjab, Pakistan. Pothwar is a rainfed area, comprising four districts of Punjab province (Attock, Chakwal, Jehlum and Rawalpindi) and Islamabad capital territory (ICT) (Fig. 1). It lies at the elevation of 350 to $575 \mathrm{~m}$ above the sea level. The total area of Pothwar region is $22000 \mathrm{~km}^{2}$. The topography of the area is undulating, generally sloping from North East to South West. The area experience semi-arid to humid climate, with annual rainfall of the area ranges from $450 \mathrm{~mm}$ in southwest to $1750 \mathrm{~mm}$ in northeast with $70 \%$ rainfall occurring during the monsoon months from July to September [25, 26]. The Pothwar Plateau has great agricultural and social significance with cultivated area of around $10000 \mathrm{~km}^{2}$. 


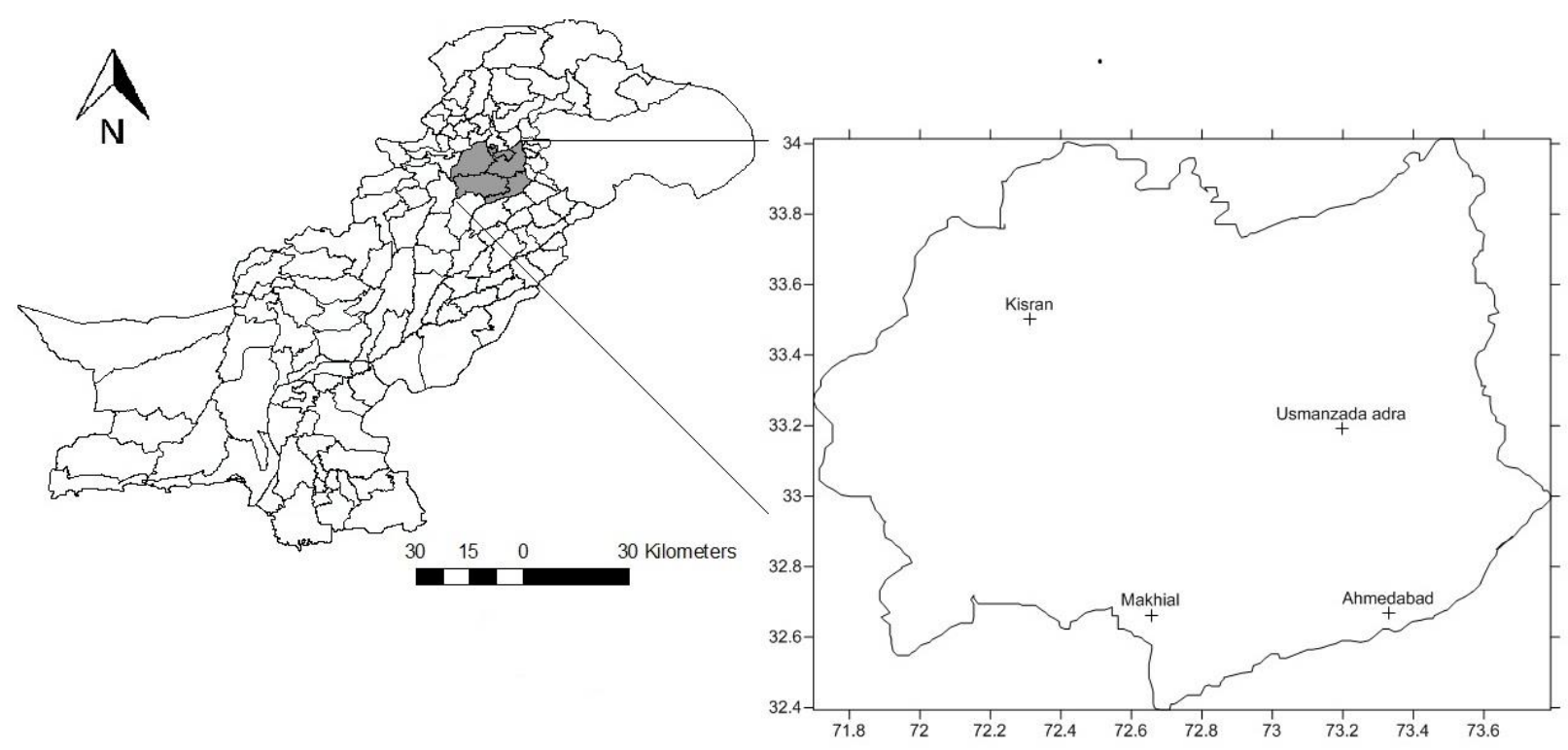

Figure 1. Map of study area, indicating the location of each of village surveyed in Pothwar, Pakistan

\section{Farmer survey}

The survey study was conducted while doing rodent trapping campaign in the rural indoor habitats of Pothwar, Pakistan between 201214. The study was conducted in four villages of the Pothwar, viz., Kisran, Ahmedabad, Makhial and Usmanzada Adra. During trapping compaign, a total of 746 small mammal species were trapped including eight rodent species and a single insectivore species. The trapped rodent species included: house mouse (Mus musculus) $(\mathrm{n}=436)$, black rat (Rattus rattus) (217), Indian gerbil (Tatera indica) (20), soft-furred field rat (Millardia meltada) (9), Indian bush rat (Golunda ellioti) (7), lesser bandicoot rat (Bandicota bengalensis) (1), short-tailed bandicoot rat (Nesokia indica) (1), and little Indian field mouse (Mus booduga) (1). Fiftyfour individuals belonged to $S$. murinus were captured.

For survey study, 30 male farmers were interviewed in each village except for village Kisran, where 24 farmers were interviewed. The survey questionnaire was adapted from previous studies undertaken in other regions of Southeast Asia [6, 27, 28], and was tailored according to the agricultural system of Pakistan. After pretesting, the survey was translated from English into Urdu (National language) to make it understandable for the farmers. There were thirty eight questions in the survey and the questionnaire was divided into three main sections. The first section summarized information on the social and demographic characteristics of the farmers (including age, family size, marital status, occupation, income, farm size and land type). The second section comprised of information on the farming practices such crops grown, constraints in crop production and status of crop pests. The third section covered farmer's knowledge and perceptions about rodent pests, damages and management practices. In order to assess their beliefs about rodents, farmers were asked a set of questions with defined responses as: true, not true, not sure/might be true. 


\section{Data analysis}

Descriptive statistics were used for the demographic characteristics. The results of the questionnaire are presented in percentages. A principal component analysis (PCA) with varimax-rotation was performed to identify the number of components for 14 items of the KAP survey, including crop production constraints and farmers beliefs and perceptions about rodent pests. An eignevalue > 1.0 was used as criteria for component extraction. All the analyses were performed using IBM SPSS Statistical Package Version 16.0.

\section{Results}

Sociodemographic characteristics of farmers

Of the 114 respondents interviewed, majority of respondents (37\%) were between 30-40 years of age. The majority of respondents were married $(82 \%)$ and the mean family size was seven $(\mathrm{SD} \pm 3.1$, range $=2-17$ ). Most of the respondents had secondary level education (33\%) or higher secondary/above $(28 \%)$. Farming was the major occupation of $42 \%$ of the respondents, the rest of them were involved in other occupations along with farming. Monthly income of $42 \%$ of the respondents ranged between 10000 and 20000PK Rupees (100-200US\$). The majority of farmers (88\%) had their own land, with average farming experience of 14.4 years $(\mathrm{SD} \pm 10.1$, range $=2-50$ years $)$ and the average land area was 2.84 ha (SD \pm 5.2 , range $=0.05-48$ ha) (Table 1$)$.

\section{Farmers' crop and pest knowledge}

Most of the farmers planted crops in both summer and winter. In Pothwar, wheat (Triticum aestivum) was the main winter crop (83\%), followed by mustard (Brassica campestris) (16\%) and legumes (1\%). Winter crops were planted in October-November and harvested in May-June. Among the summer crops, pearl millet (Pennisetum glaucum) (33\%) was the major crop, followed by sorghum (Sorghum bicolor) (30\%), maize
(Zea mays) (25\%) and peanuts (Arachis hypogaea) (11\%). In summer, farmers planted multiple crops at the same time. Summer crops were planted in July-August and harvested in September-October. The major constraint in increasing yield from agriculture fields are presented in (Table 2). The majority of farmers considered high prices of fertilizers as the major constraint in increasing yield from agriculture fields (90.6\%) followed by water shortage (90\%), low soil fertility (85\%), absence of rainfall during some years $(85 \%)$ and rodent pests $(80 \%)$ (Table 2). Across four villages, no significant differences were found among farmers concerning the problem of high prices of fertilizers $\left(\chi^{2}=11.3 \mathrm{df}=6, \mathrm{P}=\right.$ $0.06)$, water shortage $\left(\chi^{2}=11.4 \mathrm{df}=6, \mathrm{P}=\right.$ $0.28)$ and less fertile soil $\left(\chi^{2}=10.1 \mathrm{df}=6, \mathrm{P}\right.$ $=0.25$ ), but there were significant difference in the responses concerning the problem of less rainfall $\left(\chi^{2}=31.3 \mathrm{df}=6, \mathrm{P}=0.00\right)$, rodent pests $\left(\chi^{2}=17.9 \mathrm{df}=6, \mathrm{P}=0.04\right)$, low quality seed $\left(\chi^{2}=22.7 \mathrm{df}=6, \mathrm{P}=0.01\right)$ and labour cost $\left(\chi^{2}=18.5 \mathrm{df}=6, \mathrm{P}=0.05\right)$ across four study sites and with in each site (Table 2)

Farmers considered wheat as the most affected crop due to rodent pests (54\%), followed by peanuts $(32 \%)$. Harvest stage was considered as the most susceptible stage to rodent damage both in wheat (48\%) and peanuts $(44 \%)$. Some farmers perceived that rodents can be controlled more effectively at the booting stage (27\%), and an equal number of farmrers (27\%) also believed that it is impossible to control rodents at any growth stage (Fig. 2). The major pest in the crop fields were rodents (62\%), followed by insects $(20 \%)$ and wild pigs (11\%). Mostly, the farmers assessed crop losses due to rodents by observing plant damages (51\%), followed by rodent burrows (18\%), directly observing moving rodents $(14 \%)$ and their footprints $(10 \%)$. Eight of the farmers (7\%) 
assessed losses by observing multiple signs of rodent presence.

In storage, majority of the respondents identified rodents as the major pest $(61 \%)$, followed by insects (32\%). Stored food grain losses were assessed by observing the direct loss of stored grains (51\%), followed by rodent faecal droppings in grains $(20 \%)$, their footprints $(12 \%)$ and hearing rodent chirping noises or directly observing the moving rodents $(11 \%)$. Some of the responded $(6 \%)$ considered multiple signs to assess rodent damages to their stored grains.

For rodent management, farmers were using rodenticides $(74 \%)$, followed by trapping (3\%), flooding burrows (7\%) and $16 \%$ of the respondents were practicing both poisoning and trapping. Use of rodenticides was considered as more effective method (88\%) to control rodents as compared to trapping $(9 \%)$ or flooding of burrows $(5 \%)$. The majority of farmers $(58 \%)$ believed that there were no predators of rodents in the area, while $42 \%$ reported that a limited number of rodent predators existed, including domestic and feral cats (79\%), mongoose (16\%) and snakes $(4 \%)$. The majority of farmers $(81 \%)$ had no equipment/rodent trapping devices (cage traps and snap traps) for rodent control, and the main reasons identified were: their high prices (61\%), followed by nonavailability in the market (23\%) and/or their inefficiency (19\%).

\section{Farmers' beliefs and perceptions}

Farmers' perceptions about rodents were assessed through a set of questions with defined responses. Three point Likert scale was used as responses. Farmers perception about the need of rodent control showed no significant difference $\left(\chi^{2}=1.4 \mathrm{df}=6, \mathrm{P}=\right.$ 0.86 ) among respondents across the surveyed villages. Other perceptions, including crop production is affected due to rodents, rodents are sources of pathogens causing disease, collective effort by farmers can decrease loss due to rodents, all farmers cooperate in rodent management, and help or training provided by government/private sector on rodent management showed significant variation across surveyed villages and with in the same village (Table 3). Most farmers (98.1\%) believed that rodent control is needed and the crop production was affected by the rodent pests $(84.4 \%)$. The majority of farmers believed that rodents can cause diseases to people $(82.3 \%)$. Most of the respondents believed that crop production can be increased if all the farmers cooperate in rodent management $(83.7 \%)$, but eight of them $(7.4 \%)$ thought that it does not help. Most of the farmers realized that they were not cooperating with one another $(56.3 \%)$ in this regard. The role of government and/or private agencies in rodent management was reportedly not satisfactory. The majority of farmers responded that no help or training was available for rodent control (76.5\%). However, some of them were of the view that government helps them (20.8\%) (Table 3).

\section{Principal component analysis}

The Kaiser-Meyer Olkin value was calculated as 0.67, indicating that PCA on this dataset is possible. Bartlett's test of sphericity gave chi square value of 381 (significance level < 0.001). Exploratory PCA extracted five components with the cumulative variance of $63.3 \%$. In this exploratory PCA, very few items were loaded in the third, fourth and fifth components. Also, the scree plot generated for the PCA showed that only the first two components explained much of the variance in the dataset, thereby requiring a second PCA including only the factors which explain much of the variance. For the confirmation of a number of factors to be retained, we also performed Monte Carlo PCA for parallel analysis. This analysis also indicated that the first two components should be retained for further PCA. A two factor model having 39.2\% total cumulative variance was obtained. Principal component 1 (PC 1) explains $26.7 \%$ of the 
total variance and included mainly constrains items (C1-C6) and also few perception items (P2, P3 and P5). The second component (PC2) explained $12.5 \%$ of the total variance and comprises of mainly perception items (P1, P2, P4, P6 and P7) and a single constrains item (C7). "P2- Rodent control is possible" had a cross-loading over 0.4 but had its highest loading from the second factor. The items in PC1 showed high component loadings ranging from 0.405 to 0.781. Similarly, item in the PC2 showed high component loadings, ranging from 0.381 to 0.779 (Table 4 ). The component plot in rotated space indicated the first component marked by high loadings mainly for the crop production constrains (Fig. 3), the second component showed high loading for the perceptions about the rodent problem.

Table 1. Socio-demographic profile of the farmers (n-114)

\begin{tabular}{|c|c|c|c|}
\hline Parameters & Number (\%) & Parameters & Number (\%) \\
\hline Age & & Monthly Income & \\
\hline$<30$ & $20(17.5)$ & $<10000$ & $34(30)$ \\
\hline $31-40$ & $42(36.8)$ & $10000-20000$ & $47(41.5)$ \\
\hline $41-50$ & $33(28.9)$ & $20000-30000$ & $19(16.8)$ \\
\hline$>50$ & $19(16.6)$ & $>30000$ & $13(11.5)$ \\
\hline Marital status & & Source of income & \\
\hline Unmarried & $20(18)$ & Farming & $18(15.8)$ \\
\hline Married & $94(82)$ & Government service & $41(35.9)$ \\
\hline Level of Education & & Own business & $48(42.1)$ \\
\hline Illiterate & $17(15)$ & Daily Paid Labor & $7(6.1)$ \\
\hline Primary & $27(24)$ & Nature of Land type & \\
\hline Secondary & $38(33)$ & Personal & $99(87.6)$ \\
\hline Higher secondary or above & $32(28)$ & Leased & $14(12.8)$ \\
\hline \multicolumn{2}{|c|}{} & & \\
\hline Farming Experience & $14.4 \pm 10.1$ & & \\
\hline Land Area & $2.84 \pm 5.2$ & & \\
\hline Family Size & $7 \pm 3.1$ & & \\
\hline
\end{tabular}

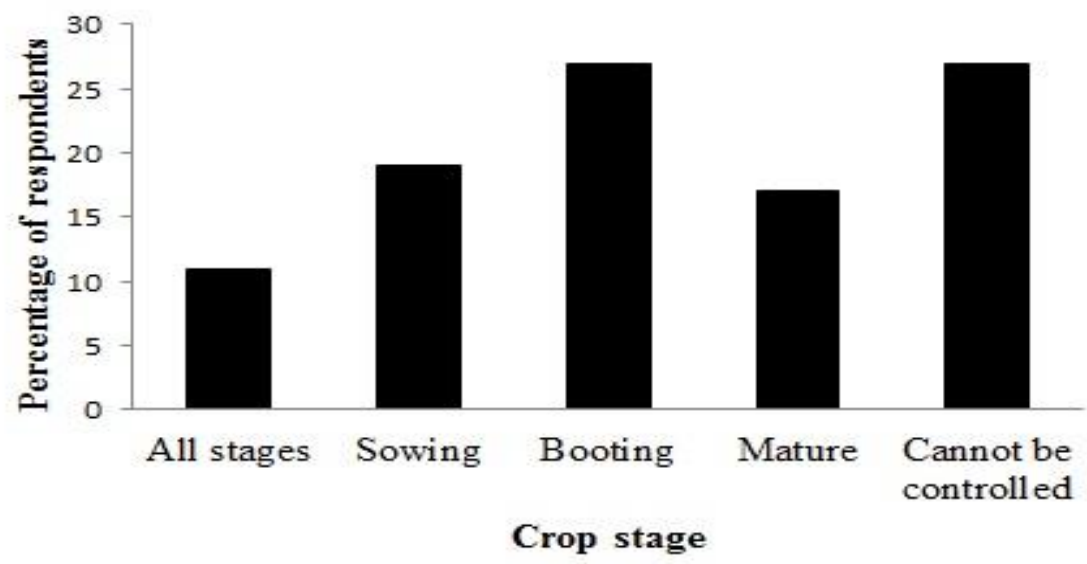

Figure 2. Farmers' ranking of different growth stages for the management of rodent pests in field crops $(n=113)$ 
Table 2. Proportion (\%) of farmers' responses to questions indicating different crop production constraints

\begin{tabular}{|c|c|c|c|c|c|c|c|c|c|}
\hline & & & & Villages & & & & & \\
\hline Constraints & Responses & Ahmedabad & Makhial & $\begin{array}{c}\text { Usmanzada } \\
\text { adra }\end{array}$ & Kisran & Total & $\begin{array}{c}\text { Chi } \\
\text { square }\end{array}$ & df & $\begin{array}{c}\text { P- } \\
\text { Value }\end{array}$ \\
\hline \multirow{3}{*}{$\begin{array}{l}\text { High prices of } \\
\text { fertilizers }\end{array}$} & Yes & 76.7 & 96.7 & 93.3 & 95.8 & 90.6 & 11.3 & 6 & 0.06 \\
\hline & No & 13.3 & 3.3 & 0.0 & 4.2 & 5.2 & & & \\
\hline & Not sure/No opinion & 10.0 & 0.0 & 6.7 & 0.0 & 4.2 & & & \\
\hline \multirow{3}{*}{ Water shortage } & Yes & 76.7 & 96.7 & 86.7 & 100.0 & 90.0 & 11.4 & 6 & 0.28 \\
\hline & No & 13.3 & 3.3 & 13.3 & 0.0 & 7.5 & & & \\
\hline & Not sure/No opinion & 10.0 & 0.0 & 0.0 & 0.0 & 2.5 & & & \\
\hline \multirow{3}{*}{ Less fertile soil } & Yes & 76.7 & 86.7 & 93.3 & 83.3 & 85.0 & 10.1 & 6 & 0.25 \\
\hline & No & 13.3 & 13.3 & 6.7 & 16.7 & 12.5 & & & \\
\hline & Not sure/No opinion & 10.0 & 0.0 & 0.0 & 0.0 & 2.5 & & & \\
\hline \multirow{3}{*}{ Rainfall problems } & Yes & 73.3 & 66.7 & 100.0 & 100.0 & 85.0 & 31.3 & 6 & 0.00 \\
\hline & No & 13.3 & 33.3 & 0.0 & 0.0 & 11.7 & & & \\
\hline & Not sure/No opinion & 13.3 & 0.0 & 0.0 & 0.0 & 3.3 & & & \\
\hline \multirow{3}{*}{ Rodent pests } & Yes & 73.3 & 69.0 & 93.3 & 83.3 & 80.0 & 17.9 & 6 & 0.04 \\
\hline & No & 13.3 & 31.0 & 6.7 & 16.7 & 16.9 & & & \\
\hline & Not sure/No opinion & 13.3 & 0.0 & 0.0 & 0.0 & 3.3 & & & \\
\hline \multirow{3}{*}{ Low quality seeds } & Yes & 46.7 & 76.7 & 93.3 & 87.5 & 76.0 & 22.7 & 6 & 0.01 \\
\hline & No & 30.0 & 13.3 & 6.7 & 12.5 & 15.6 & & & \\
\hline & Not sure/No opinion & 23.3 & 10.0 & 0.0 & 0.0 & 8.3 & & & \\
\hline \multirow{3}{*}{ Labor cost } & Yes & 50.0 & 63.3 & 89.7 & 81.8 & 71.2 & 18.5 & 6 & 0.05 \\
\hline & No & 40.0 & 36.7 & 10.3 & 18.2 & 26.3 & & & \\
\hline & Not sure/No opinion & 10.0 & 0.0 & 0.0 & 0.0 & 2.5 & & & \\
\hline
\end{tabular}


Table 3. Proportion (\%) of farmers' perceptions and beliefs towards rodent pests and their management in the Pothwar, Pakistan

\begin{tabular}{|c|c|c|c|c|c|c|c|c|c|}
\hline \multirow[b]{2}{*}{ Statements } & \multirow[b]{2}{*}{ Responses } & \multicolumn{4}{|c|}{ Villages } & \multirow[b]{2}{*}{ Total } & \multirow[b]{2}{*}{$\begin{array}{c}\text { Chi } \\
\text { Square }\end{array}$} & \multirow[b]{2}{*}{ df } & \multirow[b]{2}{*}{$\begin{array}{c}\text { P- } \\
\text { value }\end{array}$} \\
\hline & & Ahmedabad & Makhial & $\begin{array}{c}\text { Usmanzada } \\
\text { adra }\end{array}$ & Kisran & & & & \\
\hline \multirow{3}{*}{ Rodent control is needed } & Yes & 96.7 & 100.0 & 100.0 & 95.8 & 98.1 & 1.4 & 6 & 0.86 \\
\hline & No & 3.3 & 0.0 & 0.0 & 4.2 & 1.9 & & & \\
\hline & Not sure/No opinion & 0.0 & 0.0 & 0.0 & 0.0 & 0.0 & & & \\
\hline \multirow{3}{*}{ Crop production is affected due to rodents } & Yes & 63.3 & 96.7 & 90.0 & 87.5 & 84.4 & 67.7 & 6 & 0.00 \\
\hline & No & 13.3 & 3.3 & 3.3 & 12.5 & 8.1 & & & \\
\hline & Not sure/No opinion & 23.3 & 0.0 & 6.7 & 0.0 & 7.5 & & & \\
\hline \multirow{3}{*}{ Rodents are sources of disease } & Yes & 63.3 & 76.7 & 93.3 & 95.8 & 82.3 & 42 & 6 & 0.00 \\
\hline & No & 3.3 & 23.3 & 3.3 & 4.2 & 8.5 & & & \\
\hline & Not sure/No opinion & 33.3 & 0.0 & 3.3 & 0.0 & 9.2 & & & \\
\hline \multirow{3}{*}{ Collective efforts can decrease rodents losses } & Yes & 16.7 & 33.3 & 43.3 & 58.3 & 37.9 & 98 & 6 & 0.00 \\
\hline & No & 60.0 & 66.7 & 56.7 & 41.7 & 56.3 & & & \\
\hline & Not sure/No opinion & 23.3 & 0.0 & 0.0 & 0.0 & 5.8 & & & \\
\hline \multirow{3}{*}{ All farmers cooperate in rodent management } & Yes & 75.9 & 78.6 & 93.3 & 87.0 & 83.7 & 21.8 & 6 & 0.00 \\
\hline & No & 13.8 & 7.1 & 0.0 & 8.7 & 7.4 & & & \\
\hline & Not sure/No opinion & 10.3 & 14.3 & 6.7 & 4.3 & 8.9 & & & \\
\hline \multirow{3}{*}{$\begin{array}{l}\text { Help or training provided by } \\
\text { government/private sector }\end{array}$} & Yes & 10.0 & 23.3 & 16.7 & 33.3 & 20.8 & 29.8 & 6 & 0.00 \\
\hline & No & 83.3 & 76.7 & 83.3 & 62.5 & 76.5 & & & \\
\hline & Not sure/No opinion & 6.7 & 0.0 & 0.0 & 4.2 & 2.7 & & & \\
\hline
\end{tabular}


Table 4. Principal component analysis with restriction to two components (varimax rotation with kaiser normalization)

\begin{tabular}{|c|c|c|}
\hline \multirow{2}{*}{ Items } & \multicolumn{2}{|c|}{ Component } \\
\cline { 2 - 3 } & $\mathbf{1}$ & $\mathbf{2}$ \\
\hline C-2 Low quality seed & 0.781 & 0.162 \\
\hline C-6 Cost of labour & 0.624 & 0.097 \\
\hline C-4 Water shortage & 0.616 & -0.129 \\
\hline C-5 Rainfall problems & 0.611 & 0.094 \\
\hline P-3 Production effected & 0.576 & 0.223 \\
\hline C-3 High prices of fertilizer & 0.532 & 0.101 \\
\hline P-5 Collective effort by farmers can decrease loss due to rodents & 0.523 & 0.244 \\
\hline C-1 Less fertile soil & 0.515 & -0.03 \\
\hline P-2 Rodent control possible & 0.405 & 0.651 \\
\hline P-7 Help or training & 0.211 & 0.501 \\
\hline C-7 Rodent problem & 0.197 & 0.586 \\
\hline P-4 Diseases spread & 0.062 & 0.58 \\
\hline P-1 Rodent control needed & -0.012 & 0.779 \\
\hline Eigenvalues & -0.2 & 0.387 \\
\hline \% of Variance & 3.7 & 1.7 \\
\hline Cumulative \% & 26.7 & 12.5 \\
\hline & 26.7 & 39.2 \\
\hline
\end{tabular}

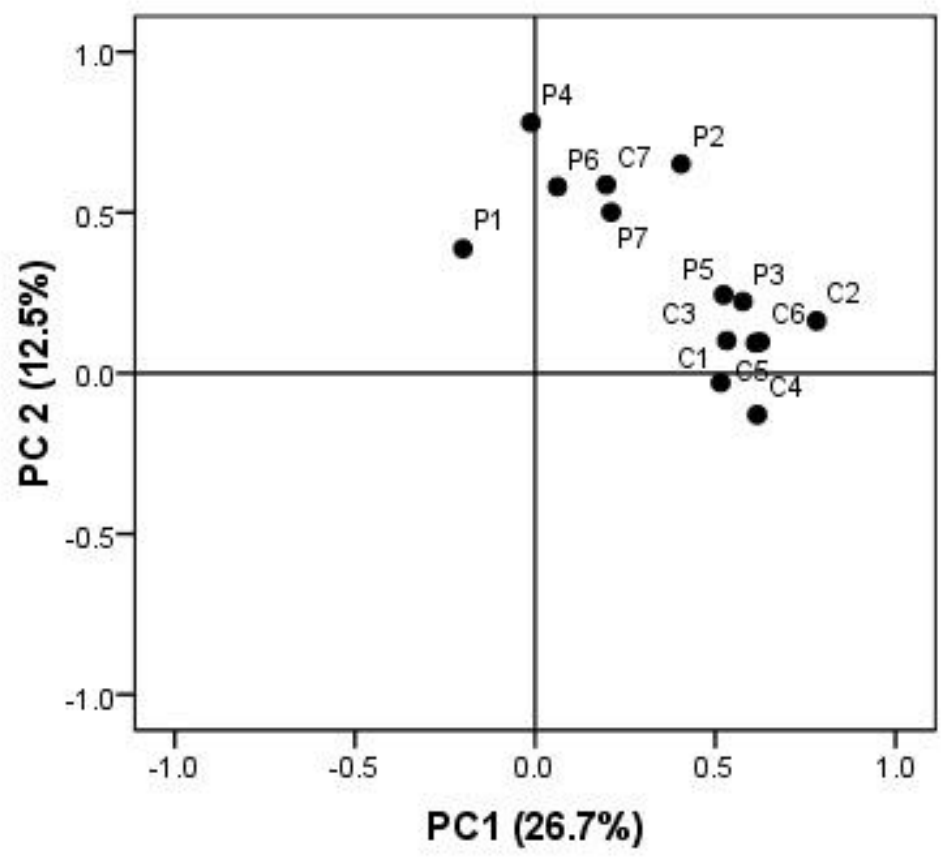

Figure 3. Principal component analysis bi-plot for the first two components 


\section{Discussion}

Farmers were well aware of the different constraints in the crop production. The majority of farmers considered rodents as an important constraint in the agricultural system of Pothwar, Pakistan. This is consistent with the previous survey in Khyber Pakhtunkhwa (KPK) province of Pakistan [29] and other parts of the world [9, $20,28,30]$, where rodents were considered as the most important pest in agricultural crops. Farmers consider booting stage in crop as an important growth phase, when rodents can be controlled more efficiently. This is consistent with previous surveys in other parts of Southeast Asia, where farmers consider booting as an important phase in rice crop to control rodents [11, 21, 27].

In Pothwar, farmers identified the harvest stage as the most critical crop stage, when rodent population is high and rodents cause serious damages. The extent of rodent damage and the most affected crop stage can vary with the cropping system of a particular area [31]. Farmers' perception about the rodent abundance and the most affected stage can be confirmed by further studies on the major ecological aspects of rodents in the Pothwar. Easy access to abundant food resources could be the possible reasons for the increase in abundance at the harvest stage. Furthermore, in most of the Asian countries, harvesting is done manually and it is generally a time taking process. This results in high exposure of crops to the pests and hence cause significant losses, particularly at the harvest stage [32].

For controlling rodents, farmers preferred rodenticides as compared to other methods. However, farmers have no background knowledge about the type of rodenticides and their correct use. Similarly, poisoning has been reported as a common control method in the Philippines [20] . In an other study, [6] reported that often rodent management fails due to lack of knowledge about the proper timing and quantity of rodenticides to be applied. Also, most of the rodenticides are not environmentally friendly, and are harmful to other non-pest species [33] and may also have hazardous effects on human health [34]. Hence, it is suggested that improper use of rodenticides should be avoided and farmers should be trained in alternative control strategies, particularly ecologically-based management practices [27]. Ecologically-based rodent management (EBRM) has been successfully implemented in some of the developing countries, including Indonesia [9] and Vietnam [34]. resulting in the reduction of $50 \%$ and $75 \%$ rodenticides use. According to [35], EBRM works successfully only if the management plan is species specific and area or habitat specific. Hence, an understanding of the population dynamics of the major rodent pest species present in Pothwar, combined with the farmers' perceptions and beliefs about rodent pests can help to develop appropriate ecologically based management strategies for the area.

Although most of the farmers believed that with cooperative efforts they can manage rodents more effectively and decrease losses in their field crops and storage, yet most of them were controlling rodents individually. Previous studies have suggested that for the implementation of successful management plans, farmers should be encouraged to work together at the community level $[20,28]$. Farmer's attitude towards rodent management practices is very important for successful implementation of any management plan and rodent infestation and crop damages can be reduced if the farmers are given proper training and education [36]. Similarly, [29] reported that the Farmers Field School (FFS) is an effective strategy to minimize pre- and post- harvest losses due to various pests. Their study showed that the farmers were most concerned with the rodent problem, because rat burrows were causing 
loss of irrigation water. Through FFS, farmers were able to minimize losses due to rodents. Our results indicated that farmers were not satisfied with the role of government sector or other private agencies in providing assistance towards rodent management practices. Hence, farmers' training is highly recommended in the area to minimize crop losses due to rodents.

\section{Conclusion}

In conclusion, rodents were considered as a major pest causing pre- and post- harvest crop losses in rural areas of Pothwar, Pakistan. Farmers considered harvest stage as the most critical stage to rodent damage. Farmers practiced rodent management individually and lacked proper training on different control strategies. Use of rodenticides as an effective method of rodent control raises environmental concerns. Hence, farmers should be trained with alternative control strategies to minimize their reliance on rodenticides. Based on the present situation, ecologically-based management strategies with a better understanding of the biology of major pest species are recommended.

\section{Authors' contributions}

Conceived and designed the experiments: $S$ Khanam \& M Mushtaq, Performed the experiments: S Khanam, Analyzed the data: S Khanam, Contributed materials/ analysis/ tools: M Mushtaq \& S Khanam, Wrote the paper: S Khanam \& M Mushtaq.

\section{Acknowledgments}

We are thankful to Higher Education Commission of Pakistan (HEC) for providing financial support for this work under grant Nos. 20-1822 and 2BMI-489 (Indigenous 5000 Ph.D fellowship program). Many thanks to the farmers for their time and cooperation during this study.

\section{References}

1. Anonymous. Economic Survey of Pakistan (2019-20), Ministry of Finance, Government of Pakistan.
2. Khan AA, Ahmed S, Hussain I \& Munir $S$ (2000). Detoriation impact of Indian crested porcupine Hystrix indica) on forest and Agriculture system in Pakistan. Int Biodeter Biodegr 45: 143-149.

3. Ali R, Mahdi F \& Khan MF (2003). Estimation of rodent damages on coconut plantation and sugar cane in Sindh. Pak $J$ Biol Sci 6: 1051-1053.

4. Ahmad E, Hussain I, Brooks JE (1995). Losses of stored foods due to rats at grain markets in Pakistan. Int Biodeter Biodegr 36: $125-133$.

5. Sang PM, Huan NH, Escalada MM \& Heong KL (2003). Farmers' beliefs and practices in rat management in the Mekong Delta, Vietnam In: Singleton GR, Hinds LA, Krebs CJ, Spratt DM, editors, Rats, mice and people: Rodent biology and management. ACIAR Monograph 96. Australian Centre for International Agricultural Research, Canberra. pp. 426430.

6. Meheretu Y, Welegerima K, Deckers S, Raes D, Makundi RH \& Leirs H (2010). Farmers' perspectives of rodent damage and management from the highlands of Tigray, Northern Ethiopian. Crop Prot 29: 532-539.

7. Palis FG, Singleton GR, Brown PR, Huan NH, Umali C \& Nga NTD (2011). Can humans outsmart rodents? Learning to work collectively and strategically. Wildlife Res 38: 68-578.

8. Brown PR \& Khamphoukeo K (2010). Changes in farmers' knowledge, attitudes and practices after implementation of ecologically-based rodent management in the uplands of Lao PDR. Crop Prot 29: 577-582.

9. Makundi RH, Bekele A, Leirs H, Massawe AW, Rwamugira W \& Mulungu LS (2005). Farmer's perceptions or rodents as crop pests: knowledge, attitudes and practices in rodent pest management in 
Tanzania and Ethiopia. Belg J Zool 135: 153-157.

10. Sudarmaji, Singleton GR, Herawati NA, Djatiharti A \& Rahmini (2003). Farmers' perceptions and practices in rat management in West Java, Indonesia. In: Singleton GR, Hinds LA, Krebs CJ, Spratt DM, editors, Rats, mice and people: Rodent biology and management. ACIAR Monograph 96. Australian Centre for International Agricultural Research, Canberra, pp. 389-394.

11. Tuan NP, Williams SJ, Brown PR, Singleton GR, Tan TQ, Hue DT, Ha PTT \& Hoa PT (2003). Farmers' perceptions and practices in rat management in Vinh Phuc Province, northern Vietnam. In: Singleton GR, Hinds LA, Krebs CJ, Spratt DM, editors, Rats, mice and people: Rodent biology and management. ACIAR Monograph 96. Australian Centre for International Agricultural Research, Canberra. pp. 399-402.

12. Brown PR \& Khamphoukeo K (2010). Changes in farmers' knowledge, attitudes and practices after implementation of ecologically-based rodent management in the uplands of Lao PDR. Crop Prot 29: 577-582.

13. Singleton GR, Sudarmaji, Jacob J \& Krebs CJ (2005). Integrated management to reduce rodent damage to lowland rice crops in Indonesia. Agric Ecosyst Environ 107: 75-82.

14. Bekele A, Leirs H \& Verhagen R (2003). Composition of rodents and damage estimates on maize farms at Ziway, Ethiopia. In: Singleton GR, Hinds LA, Krebs CJ, Spratt DM, editors, Rats, mice and people: Rodent biology and management. ACIAR Monograph 96. Australian Centre for International Agricultural Research, Canberra. pp. 262263.

15. Mdangi M, Mulungu LS, Massawe AW, Eiseb SJ, Tutjavi V, Kirsten F, Mahlaba T,
Malebane P, Maltitz EV, Monadjem A, Dlamini N, Makundi RH \& Belmain SR (2013). Assessment of rodent damage to stored maize (Zea mays L.) on smallholder farms in Tanzania. Int J Pest Manage 59: 55-62.

16. Brown PR, McWilliam A \& Khamphoukeo K (2013). Post-harvest damage to stored grain by rodents in village environments in Laos. Int Biodeter Biodegr 82: 104-109.

17. Belmain SR, Htwe NM, Kamal NQ \& Singleton GR (2015). Estimating rodent losses to stored rice as a means to assess efficacy of rodent management. Wildlife Res 42: 132-142.

18. Santra KB \& Manna CK (2008). Studies of some aspects of rodent ecology in the four districts of the gangetic plain of West Bengal, India. Univ J Zool. Rajshahi Univ 27: 85-90.

19. Meerburg BG, Singleton GR \& Leirs H (2009). The year of the rat ends - time to fight hunger! Pest Manag Sci 65: 351-352.

20. Stuart AM, Prescott CV, Singleton GR \& Joshi RC (2011). Knowledge, attitudes and practices of farmers on rodent pests and their management in the lowlands of the Sierra Madre Biodiversity Corridor, Philippines. Crop Prot 30: 147-154.

21. Brown PR, Yee N, Singleton GR, Kenney AJ, Htwe NW, Myint M \& Aye T (2008). Farmers' knowledge, attitude and practices for rodent management in Myanmar. Int J Pest Manage 54: 69-76.

22. Brown PR, Tuan NP, Singleton GR, Ha PTT, Hoa PT, Hue DT, Tan TQ, Tuat NV, Jacob J \& Muller WJ (2006). Ecologically- based management of rodents in the real world: application to a mixed agro-ecosystem in Vietnam. Ecol Appl 16: 2000-2010.

23. Palis FG, Singleton GR, Belmain SR, Brown PR \& Hardy B (2010). Sociocultural factors influencing the adoption of ecologically based rodent pest 
management. In: Singleton GR, Belmain SR, Brown PR, Hardy B, editors. Rodent outbreaks: ecology and impacts. Los Baños (Philippines): International rice research institute, pp. 153-170.

24. Hussain I, Cheema AM, Khan AA (2003). Small rodents in the crop ecosystem of Pothwar Plateau, Pakistan. Wildlife Res 30: 269-274.

25. Rashid K and Rasul G (2011). Rainfall variability and maize production over the Potohar Plateau of Pakistan. Pak J Meteorol 8: 63-74.

26. Tariq AR (2004). Hydrologic assessment of small dams in Potohar area: Case study of Jammergal Dam. Pakistan Engineering Congress, 69th Annual Session Proceedings; Lahore, Pakistan.

27. Brown PR \& Khamphoukeo K (2007). Farmers' knowledge, attitudes, and practices with respect to rodent management in the upland and lowland farming system of the Lao People's Democratic Republic. Integr Zool 2: 165173.

28. Joshi RC, Matchoc ORO, Bahatan RG \& Dela Pena FA (2000). Farmers' knowledge, attitudes and practices of rice crop and pest management at Ifugao Rice Terraces, Philippines. Int J Pest Manage 46: 43-48.

29. Khatam A, Muhammad S \& Ashraf I (2014). Perceived effect of farmers field school approach on capacity building in controlling pre and post harvest losses. $J$ Agr Sci Tech 16: 759-765.

30. Yonas M, Welegerima K, Deckers S, Raes D, Makundi R \& Leirs H (2010).
Farmers' perspectives of rodent damage and management from the highlands of Tigray, Northern Ethiopian. Crop Prot 29: 532-539.

31. Stuart AM, Prescott CV \& Singleton GR (2014). Habitat manipulation in lowland rice-coconut cropping systems of the Philippines - an effective rodent pest management strategy. Pest Manag Sci 70: 939-945.

32. Parshad VR (1999). Rodent control in India. Integrated Pest Management Reviews 4: 97-126.

33. Brakes CR \& Smith RH (2005). Exposure of non-target small mammals to rodenticides: short-term, recovery and implications for secondary poisoning. $J$ Appl Ecol 42: 118-128.

34. Belmain SR, Meyer AN, Penicela L \& Xavier R (2002). Population management of rodent pests through intensive trapping inside rural households in Mozambique. In: Jones SC, J. Zhai J, Robinson WH editors, Proceedings of the $4^{\text {th }}$ International conference on urban pests (ICUP). Charleston. pp. 421-428.

35. Singleton GR, Brown PR \& Jacob J (2004). Ecologically based rodent management; its effectiveness in cropping systems in South-East Asia. Neth J Agric Sci 52: 163-171.

36. Babbar BK, Singla N \& Singh R (2014). Impact of village level education and training on adoption of control strategies, their sustainability and reduction in crop losses. Int J Adv Res 2: 672-683. 